Winter 2008

\title{
The Foreign Corrupt Practices Act, OPIC, and the Retreat from Transparency
}

Blake Puckett

Yale Law School

Follow this and additional works at: https://www.repository.law.indiana.edu/ijgls

Part of the Civil Law Commons, Comparative and Foreign Law Commons, and the International Law Commons

\section{Recommended Citation}

Puckett, Blake (2008) "The Foreign Corrupt Practices Act, OPIC, and the Retreat from Transparency," Indiana Journal of Global Legal Studies: Vol. 15 : Iss. 1 , Article 7.

Available at: https://www.repository.law.indiana.edu/ijgls/vol15/iss1/7

This Symposium is brought to you for free and open access by the Law School Journals at Digital Repository @ Maurer Law. It has been accepted for inclusion in Indiana Journal of Global Legal Studies by an authorized editor of Digital Repository @ Maurer Law. For more information, please contact rvaughan@indiana.edu.

\section{$\Psi$}

JEROME HALL LAW LIBRARY

INDIANA UNIVERSITY

Maurer School of Law
Blooming ton 


\title{
The Foreign Corrupt Practices Act, OPIC, and the Retreat from Transparency
}

\author{
Blake Puckett*
}

\begin{abstract}
This article argues that the current intersection of the Foreign Corrupt Practices Act (FCPA) and the Overseas Private Investment Corporation (OPIC) is turning U.S. investment and aid policy in a direction that neither addresses corruption concerns, nor augments other U.S. foreign policy goals in the Caucasus and Central Asia, and perhaps more globally. The current regulatory system has caused OPIC to structure its investment projects in alternative forms that bypass anti-corruption regulations. While these alternatives serve to increase capital in developing economies, the distance they create between $O P I C$ and the end-user fosters a lack of transparency and ultimately corruption. However, improvements in transparency combined with a restructuring of the OPIC system can create an investment system that addresses U.S. foreign policy concerns.
\end{abstract}

\section{INTRODUCTION}

This article argues that the current intersection of the Foreign Corrupt Practices Act (FCPA) and the Overseas Private Investment Corporation (OPIC) is turning U.S. investment and aid policy in a direction that neither addresses corruption concerns, nor augments other U.S. foreign policy goals in the Caucasus and Central Asia, and perhaps more globally.

My argument starts with two premises: (1) that Foreign Direct Investment (FDI) is a major contributor to growth and poverty reduction in developing countries and (2) that FDI that is identifiably American augments U.S. influence in a region where that influence is in competition with other significant powers. ${ }^{1}$ Ac-

* Yale Law School, 1999, Ph.D. candidate in Law \& Social Science at Indiana University School of Law-Bloomington.

1. These are clearly arguable assumptions, but for the purpose of this article I proceed as if they are true.

Indiana Journal of Global Legal Studies Vol. 15 \#1 (Winter 2008)

OIndiana University School of Law 
cording to Michael Klein et al., FDI is a key component in the global fight against poverty. He argues that this is because the "very essence" of economic development is the transfer of knowledge, techniques, and "best practices" and that FDI is particularly well suited to stimulate this transfer, while also stimulating growth, another key component in poverty reduction. ${ }^{2}$ In contrast, various methods of Foreign Portfolio Investing, ${ }^{3}$ while currently very popular with OPIC, do not contribute to transparency initiatives, may be less effective at economic growth, ${ }^{4}$ and do not increase U.S. political capital.

In Part I, I proceed by first laying out the requirements of the FCPA. In Part II, I then consider the levels of corruption in the Caucasus and Central Asia. Part III then analyzes OPIC's investments in the region. I conclude that the high levels of corruption are having a marked effect on OPIC investment and then hypothesize that one reason for OPIC's turn to alternative investment schemes is indirectly related to bypassing anti-corruption regulations. In Part IV, I analyze these alternative funding schemes for their ability to expose corruption and promote transparency and democratic governance. I conclude in Part V that these alternative schemes, like many current trends in free-market globalization, will only serve to increase the democracy deficit and instead propose an alternative role for OPIC.

\section{The Foreign Corrupt Practices Act}

The Foreign Corrupt Practices Act (FCPA), originally passed in 1977, seeks to prevent the paying of bribes, either directly or indirectly, to foreign officials, by U.S. companies or individuals. For much of the 1990s the United States remained the only country whose laws forbid corrupt payments to foreign officials. ${ }^{5}$ While this has

2. Michael Klein, et al., Foreign Direct Investment and Poverty Reduction 2 (World Bank, Policy Research Working Paper No. 2613, 2001), available at http://ssrn.com/abstract=632682.

3. April M. Knill, Can Foreign Portfolio Investment Bridge the Small Firm Financing Gap around the World? $2 \mathrm{n} .1$ (World Bank, Policy Research Working Paper 3796, 2005) available at http://papers .ssrn.com/sol3/papers.cfm?abstract_id $=753605$ ("Foreign portfolio investment is defined by the IMF (Balance of Payments Manual (1993)) as equity and debt issuances including country funds, depository receipts and direct purchases by foreign investors of less than $10 \%$ control. Foreign direct investment is defined as investment that is concerned with longer-term ownership or a controlling interest of more than $10 \%$."). I generally follow this definition, although I think long-term FDI is distinct from shorter term controlling interests.

4. Klein, et al., supra note 2, at 8 (arguing that portfolio investors run a greater risk of asset stripping).

5. Jeffrey P. Bialos \& Gregory Husisian, The Foreign Corrupt Practices Act: Coping with Corruption in Transitional Economies 4 (1997). 
begun to change with the passage of the Organization for Economic Cooperation and Development's (OECD) Convention on Combating Bribery of Foreign Public Officials in International Business Transactions in 1997, only half had enacted implementing legislation by the close of $1999 .{ }^{6}$ Similarly, the Council of Europe's Criminal Law Convention of Corruption, while opened for signature in 1999, entered into force only in July 2002 after its ratification by fourteen members. ${ }^{7}$ Even assuming actual executive implementation at the national level among OECD and EU members of what has largely been a U.S. push against corruption, the fruit of such action would only recently have had an effect. ${ }^{8}$ Despite the growing focus on corruption internationally, U.S. based companies remain at the forefront of the fight against corruption, especially in light of the growing nexus between Sarbanes-Oxley governance and reporting requirements and Foreign Corrupt Practices Act investigations. ${ }^{9}$

\section{A. Elements}

The Foreign Corrupt Practices Act makes it illegal for U.S. persons, including natural persons, ${ }^{10}$ domestic concerns, ${ }^{11}$ and companies registered with or required to file reports to the SEC, ${ }^{12}$ to make corrupt payments to a foreign official for the purpose of obtaining or retaining business. Since its amendment in 1998, the FCPA has also applied to foreign persons and firms who take such acts within the United States..$^{13}$

6. OECD, OECD Steps Taken By State Parties to Implement and Enforce the Convention on Combating Bribery of Foreign Public Officials in International Business Transactions, Submissions as of August 2007, available at http://www.oecd.org/dataoecd/50/33/1827022.pdf [hereinafter OECD Steps Taken].

7. Criminal Law Convention on Corruption, Jan. 27, 1999, Europ. T.S. No. 173, available at http://conventions.coe.int.

8. Peter W. Schroth, The United States and the International Bribery Conventions, 50 Ам. J. Сомp. L. 593, 610-22 (2002).

9. Kevin Lacroix, FCPA: A 70's Revival, THE D \& O DiARY, May 16, 2006, http:/dandodiary. blogspot.com/2006/05/fcpa-70s-revival.html ("Sarbanes-Oxley's requirements that senior management assess their internal controls and verify their financial statements, including the requirement that companies identify any material weakness, are increasing management scrutiny and leading to the identification of more FCPA concerns. Companies are obligated to report potential FCPA violations").

10. 15 U.S.C. $\$ 78 \mathrm{dd}-3$ (2006).

11. Id. at $\S 78 \mathrm{dd}-2$.

12. Id. at $\$ 78 \mathrm{dd}-1$.

13. U.S. Department of Justice, Foreign Corrupt Practices Act Antibribery Provisions, in LAY PERson's Guide to FCPA [hereinafter DOJ Guide], http://www.usdoj.gov/criminal/fraud/docs/ dojdocb.html (last visited March 28, 2008). 
According to Robert Tarun, there are five elements of an anti-bribery prohibition violation:

(1) a payment of - or an offer, authorization, or promise to paymoney or anything of value, directly, or through a third party;

(2) to (a) any foreign official, (b) any foreign political party or party official, (c) any candidate for foreign political office, (d) any official of a public international organization, or (e) any other person while 'knowing' that the payment or promise to pay will be passed on to one of the above;

(3) the use of an instrumentality of interstate commerce (such as telephone, telex, email, or the mail) by any person (whether U.S. or foreign) or an act outside the U.S. by a domestic concern or U.S. person, or an act in the United States by a foreign person in furtherance of the offer, payment or promise to pay;

(4) for the corrupt purpose of influencing an official act or decision of that person, inducing that person to do or omit to do any act in violation of his or her lawful duty, securing any improper advantage, or inducing that person to use his influence with a foreign government to affect or influence any government act or decision;

(5) in order to assist the company in obtaining or retaining business or in directing business to any person or to secure an improper advantage. $^{14}$

\section{B. Penalties}

Penalties for the violation of the FCPA range from fines of up to $\$ 10,000$ for individuals who did not commit a willful violation ${ }^{15}$ to $\$ 100,000$ and five years in

14. Robert W. Tarun, Basics of the Foreign Corrupt Practices Act, What Every General Counsel, Transactional Lawyer and White Collar Criminal Lawyer Should Know (Latham \& Watkins, Chicago, Ill.), May 2, 2006, at 3, http://www.lw.com/upload/pubContent/_pdf/pub1287_1.pdf. Tarun draws from 15 U.S.C. $\$ \S 78 \mathrm{dd}-1$ (a), 78dd-2(a), and $78 \mathrm{dd}-3$ (a) for this summary.

15. 15 U.S.C. $\S 78 \mathrm{dd}-2(\mathrm{~g})(2)(\mathrm{B}), \S 78 \mathrm{dd}-3$ (e)(2)(B), § $78 \mathrm{ff}(\mathrm{c})(2)(\mathrm{B})(2006)$. 
prison for willful violations. ${ }^{16}$ Corporations may be fined up to $\$ 2,000,000$ for violations of the FCPA. ${ }^{17}$ Like other violations of the reporting requirements of the Exchange Act of 1933, attempts to evade the FCPA by making false and misleading statements in filings by corporations required to submit reports to the SEC may lead to penalties of up to $\$ 5,000,000$ and twenty years in prison for natural persons and up to $\$ 25,000,000$ for juridical persons. ${ }^{18}$ In addition, under the Criminal Fine Improvements Act of 1987 the maximum penalty may be increased to up to twice the gross gain..$^{19}$ Other liabilities for bribing foreign officials beyond those provided for in the FCPA include additional fines by the SEC, injunctions to cease and desist, suspension of any business with the U.S. government, denial of export licenses, and treble damages under the Racketeer Influenced and Corrupt Organizations Act (RICO) if sued by a competitor harmed by the corrupt act. ${ }^{20}$ For individuals, fines imposed under the FCPA cannot be paid by the company or concern, either directly or indirectly. ${ }^{21}$

\section{Loopholes}

Given the broad sweep of the FCPA and the liability if found guilty of violations-particularly the potential for jail time-corporations and their employers are rightly concerned about avoiding liability. However, there are several limitations on the reach of the FCPA. First, the FCPA docs not apply to what is commonly called "facilitating" or "grease payments." The purpose of this exception is to allow the payments of small sums to low-ranking government officials to do a routine action that they should be doing anyway. ${ }^{22}$ There is however a gray area between legitimate facilitating payments and payments that corruptly influence a government official. ${ }^{23} \mathrm{Also}$, under the FCPA, not every gift given to a foreign official is considered a bribe. Under the FCPA payments made in the course of lob-

16. $I d$. at $\$ \S 78 \mathrm{dd}-2(\mathrm{~g})(2)(\mathrm{A}), \S 78 \mathrm{dd}-3(\mathrm{e})(2)(\mathrm{A}), \S 78 \mathrm{ff}(\mathrm{c})(2)(\mathrm{A})$.

17. 15 U.S.C. $\S 78 \mathrm{dd}-2(\mathrm{~g})(1)(\mathrm{A}), \S 78 \mathrm{dd}-3(\mathrm{e})(\mathrm{l})(\mathrm{A}), \S 78 \mathrm{ff}(\mathrm{c})(\mathrm{l})(\mathrm{A})$.

18. Id. at $\S 78 \mathrm{ff}(\mathrm{A})$.

19. 18 U.S.C. $\S 3571$ (d) (2006).

20. DOJ Guide, supra note 13.

21. 15 U.S.C. $\$ 78 \mathrm{dd}-2(\mathrm{~g})(3), \S 78 \mathrm{dd}-3(\mathrm{e})(3), \S 78 \mathrm{ff}(\mathrm{c})(3)$.

22. Id. at $\$ 78 \mathrm{dd}-2$ (b) (2006).

23. In United States v. Vitusa Corporation the Department of Justice prosecuted Vitusa Corporation for a payment to a government official to expedite and secure the payment of a debt that all agreed was owed to Vitusa. Rebecca Koch, Note, The Foreign Corrupt Practices Act: It's Time to Cut Back the Grease and Add Some Guidance, 28 B.C. InT'L. Comp. L. Rev. 379, 391-92 (2005). 
bying, motivated by "some generalized hope or expectation of ultimate benefit" are legal; only those payments made in exchange for a quid pro quo are prohibited. ${ }^{25}$ While differentiating a regular lobbying fee from a fee intended as part of a quid pro quo can be difficult, some firms will choose to take the risk.

The FCPA also provides two affirmative defenses. The person charged may assert that the payment "was lawful under the written laws and regulations" of the payee's country. ${ }^{26}$ Alternatively, the person charged may assert that the payment was a "reasonable and bona fide expenditure, such as travel and lodging incurred by or on behalf of a foreign government official ... directly related to (A) the promotion, demonstration, or explanation of products or services; or (B) the execution or performance of a contract with a foreign government." ${ }^{27}$ Even if only normal and reasonable expenses are paid, the U.S. governmental per diem rate on a trip to the United States would be considered a very desirable perquisite in the eyes of many bureaucrats abroad who earn official salaries of less than $\$ 100$ per month.

Requesting an advisory opinion from the Department of Justice (DOJ) is another method for parties to avoid liability. To obtain an advisory opinion, the request must relate to an actual transaction, not just a hypothetical one. The request must be specific and the DOJ can request additional information to clarify matters. If a favorable opinion is granted then a rebuttable presumption is created that the described conduct is permitted under the FCPA. However, corporations have generally been reluctant to use the advisory opinion procedure due to concerns about loss of confidentiality, the possibility of a negative answer, and fears of further governmental investigation. ${ }^{28}$

An alternative to the external advisory opinion is an internal risk analysis. Bialos and Husisian suggest that by using a risk management approach, firms may decide that the relatively low risk of a corrupt payment actually occurring, becoming known, and being prosecuted may be outweighed by the potential

24. United States v. Arthur, 544 F.2d 730, 734 (4th Cir. 1976).

25. Bialos \& Husisian, supra note 5, at 35.

26. 15 U.S.C. $§ \S 78 d d-1$ (c)(1), 78dd-2(c)(1) (2006). An interesting possibility exists where service fees, generally a euphemism for corrupt payments, are required by the foreign government. See U.S. Department of Justice, Foreign Corrupt Practices Act Review Opinion Procedure Release, No. 93-2 (May 11, 1993) [hereinafter FCPA OPR], http://www.usdoj.gov/criminal/fraud/fcpa/ opinion/1993/9302.html.

27. 15 U.S.C. $\S \S 78 \mathrm{dd}-1$ (c)(2), $78 \mathrm{dd}-2$ (c)(2) (2006). But see Tarun, supra note 14 , at $6-7$ (noting that the Department of Justice took action against a company that both paid for first class airfare, food, and lodging, and provided a lump sum "per diem").

28. Tarun, supra note 14 , at 9 . 
gain. ${ }^{29}$ While this may indeed be true for a corporation, it is likely not true for individuals. The risk analysis approach is based on the idea of profit or losses, and not on potential jail time. For individuals, the potential for criminal liability, including incarceration, however remote, will be a much greater impediment to potential projects. Knowledge that the intelligence community is actively monitoring foreign corporations for illicit payments and that other nations may do the same to U.S. corporations should only further serve to limit the willingness of boards of directors to support projects where violation of the FCPA is likely. ${ }^{30}$

\section{Compliance Programs}

Establishing a corporate compliance program is a common method of avoiding liability. Under the Organizational section of the U.S. Sentencing Guidelines, the "existence of an effective compliance and ethics program" can serve as a mitigating factor in the ultimate punishment of an organization. ${ }^{31}$ An effective FCPA compliance program would include the monitoring of agents, consultants, and representatives to ensure they are not engaging in conduct on behalf of the corporation that potentially violates the FCPA..$^{32}$ A compliance program would also include the establishment of a set of warning signs or red flags that would cause a corporation and its legal counsel to more closely consider a transaction before moving forward. ${ }^{33}$

Examples of flags that are particularly relevant to working in the Caucasus and Central Asia include:

- "the transaction involves or takes place in a country with a general reputation for bribery and corruption;" 34

- "there is lack of transparency in expenses and accounting records;";

- "the agent or consultant has a close family connection with or

29. Bialos \& Husisian, supra note 5, at 74-84.

30. Id. at 119 (noting that the CIA and the NSA both used intelligence collection capabilities to accumulate evidence of bribery by firms competing against U.S. firms for lucrative governmental contracts).

31. U.S. Sentencing Guidelines Manual ch.8, introductory cmt. (2006), available at hitp:// www.ussc.gov/2006guid/CHAP8.pdf.

32. Tarun, supra note 14 , at $19-21$.

33. See id. at 24; see also Bialos \& Husisian, supra note 5, at App. 3-6.

34. Tarun, supra note 14 , at 26.

35. Id. 
other personal or professional affiliation with the foreign government or officials;" ${ }^{36}$

- "the agent or consultant has been recommended to the company by a foreign official of the potential government customer;";7

- "the agent or consultant refuses to sign representations, warranties and covenants that he/she has not violated and will not violate the requirements of the FCPA;";8

- "widespread news accounts of payoffs, bribes, or kickbacks;"39

- "the industry involved has a history of FCPA violations. These industries include defense, aircraft, oil, and construction services;" ${ }^{30}$

- "the agent or consultant requests payment in cash;"41 and

- unusually high commission rates are requested compared to the going rate in the country and business. ${ }^{42}$

A failure to take note of these warning signs would likely be considered a lack of due diligence, with the commensurate loss of the benefits of having a compliance program under the Federal Organizational Sentencing Guidelines. ${ }^{43}$

\section{Transparency International, Corruption, and Central Asia}

For a company considering investing in the Caucasus or Central Asia, what would an effective corporate compliance program conclude? The first warning sign for any potential investor would be the extent to which the country or region is known for a climate of corruption or bribery. According to Transparency International, a leading global organization dedicated to fighting corruption, the former Soviet states of the Caucasus and Central Asia are among the most corrupt in the world. Transparency International issues an annual Corruption Perceptions Index that "ranks more than 150 countries by their perceived level of corruption,

36. $1 d$. at 25.

37. Id.

38. Id.

39. Bialos \& Husisian, supra note 5, at App. 3.

40. Id.

41. Ta run, supra note 14, at 25.

42. Id.

43. See id. at 21-23; see also U.S. Sentencing Comm'n Organizational Guidelines and ComPLIANCE, available at http://www.ussc.gov/orgguide.htm. (last visited June 13, 2008) 
as determined by expert assessments and opinion surveys. ${ }^{34}$ The rankings of the Caucasus and Central Asian states in 2004, 2005, and 2006 were as follows:

Table 1. Level of corruption of the Caucasus and Central Asian states 2004-2006

\begin{tabular}{|l|l|l|l|}
\hline Country & 2004 (of 145$)$ & 2005 (of 158) & 2006 (of 163) \\
\hline Armenia & 82 & 88 & 93 \\
\hline Azerbaijan & 140 & 137 & 130 \\
\hline Georgia & 133 & 130 & 99 \\
\hline Kazakhstan & 122 & 107 & 111 \\
\hline Kyrgyzstan & 122 & 130 & 142 \\
\hline Tajikistan & 133 & 144 & 142 \\
\hline Turkmenistan & 133 & 155 & 142 \\
\hline Uzbekistan & 114 & 137 & 151 \\
\hline
\end{tabular}

Source: Transparency International, Corruption Perceptions Index (2004-2007),

http://www.transparency.org/policy_research/surveys_indices/cpi.

Of the eight countries, only Armenia avoided being labeled as one of the thirty-five "worst countries" in 2004, and in 2005 six of eight remained in the thirty worst, with Kazakhstan joining Armenia in the middle range of the corruption index. ${ }^{45}$ Only Georgia has seen a recent marked improvement, commensurate with the intense anti-corruption efforts by the new Georgian government after the 2003 Rose Revolution. ${ }^{46}$

Other indicators of corruption in the region are numerous. "Kazakhgate," the prosecution of a U.S. citizen for bribes and corruption related to oil and gas investments in Kazakhstan, has implicated the President of Kazakhstan. ${ }^{47}$ U.S. Ambassador Harnish gave a speech at an investment conference in Azerbaijan in November 2004 in which he highlighted a number of issues-all centering around the difficulties U.S. companies were facing in operating in Azerbaijan, particularly with governmental entities. ${ }^{48}$ U.S. embassy officials in other countries

44. Transparency International, Corruption Perceptions Index (2004-2007), http://www.trans parency.org/policy_research/surveys_indices/cpi.

45. Id.

46. Angela Hawken \& Jonathan D. Kulick, Civil-Service Views on Official Corruption and Leadership in Georgia (Sept. 30, 2006) (unpublished manuscript, on file with author).

47. United States v. Giffen, 326 F. Supp. 2d 497 (S.D.N.Y. 2004).

48. Reno Harnish, Ambassador to Azer., Improving the Business Climate in Azerbaijan, Address at the Ministry of Econ. Dev. of Azer. Conference: Business Climate of Azerbaijan: Achievements 
have also addressed the issue ${ }^{49}$ and personal accounts from those working in the region are usually full of examples. ${ }^{50}$

Given the high levels of corruption reported, an effective FCPA compliance program should raise a number of red flags and suggest that U.S. investors steer clear of the region. This has actually occurred in some cases, with Bechtel deciding not to invest in Turkmenistan because they deemed it impossible to act there without violating the FCPA..$^{51}$ Even with various "loopholes," the liabilities involved with violations of the FCPA and related statutes make it notable that OPIC has provided financing and/or insurance for a significant number of projects involving U.S. companies in Central Asia and the Caucasus since 1991.

\section{Overseas Private Investment Corporation}

OPIC is an independent agency established by the U.S. government in 1971 as a continuation of programs originally part of the Marshall Plan. ${ }^{52}$ According to its statutory underpinnings, the mission of OPIC is "to mobilize and facilitate the participation of United States private capital and skills in the economic and social development of less developed countries and areas, and countries in transition from nonmarket to market economies, thereby complementing the development assistance objectives of the United States. ${ }^{1{ }^{3}}$ In furthering this goal, Congress has provided several additional guidelines for considering projects, including funding projects that complement

and Problems (Nov. 16, 2004), available at http://azerbaijan.usembassy.gov/fambspll1604.html.

49. Marie Yovanovitch, U.S. Ambassador to Kyrgyz Republic, Ambassador's Op-Ed on One Year Anniversary of March 24th "Tulip Revolution" (Mar. 24, 2006), http://kyrgyz.usembassy. gov/ambassadors_op-ed_on_one_year_anniversary_of_march_24th_tulip_revolution.html; Nargis Zakirova, Tajikistan: Clock Ticking on Corruption, Institute for War and Peace Report-

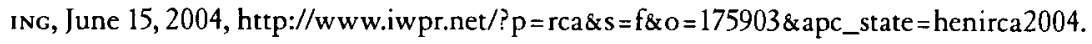

50. Though one recent World Bank study had over $50 \%$ of firms in the Southern CIS reporting little or no corruption this survey was likely skewed by participants either reluctant to confirm corruption or else tied to the current power regime and as such beneficiaries of the corruption. JAMES Anderson \& Cheryl Grey, Anti-Corruption in Transition 3: Who is Succeeding...and Why? 14, 31 (2006) (noting that Belarus and Uzbekistan, two countries with the least progress in transition, also showed the largest deviation between the survey results and the opinions of outside experts).

51. Timothy Ashby, Steering Clear of the Foreign Corrupt Practices Act, 45 Orange County Law. 10,11 (2003).

52. OPIC, Program Handbook 5 (2005), http://www.opic.gov/pdf/05_ProgramHandbook. pdf [hereinafter Program Handbook]; Charles D. Toy, The Role of the Bilateral Agencies, Powerpoint Slides in Project Financing in Emerging Markets, at 119, 124 (PLi Comm. L. \& Prac., Course Handbook Series No. 809, 2000).

53. 22 U.S.C.A. $\$ 2191(2000)$. 
"other development assistance programs," ${ }^{, 4}$ preferring projects in countries with a per capita income of $\$ 984$ or less, 55 and preferring projects by U.S. small businesses. ${ }^{56}$ At the same time OPIC is to ensure that projects are compatible with environmental protection, ${ }^{57}$ promote private enterprise, ${ }^{58}$ initiative, and competition, ${ }^{59} \mathrm{do}$ not result in a "significant reduction in the number of employees in the United States," ${ }^{100}$ and do not contain "performance requirements which would reduce substantially the positive trade benefits likely to accrue to the United States." ${ }^{\text {.1 }}$ Finally, OPIC must do all this while furthering "to the greatest degree possible, in a manner consistent with its goals, the balance-of-payments and employment objectives of the United States. ${ }^{.62}$

\section{A. Tools}

OPIC has three tools to accomplish its mission: (1) financing for private investors, (2) political risk insurance, and (3) support to investment funds..$^{63}$ According to OPIC's current Program Handbook, projects it supports require financial viability and significant U.S. involvement in an eligible country that is "responsive to the development needs of the host country," and "not likely to harm the U.S. economy or have a negative effect on U.S. employment." OPIC is required to conduct an environmental assessment of every project. The project cannot "contribute to the violation of workers rights" or "involve illicit payments,"64 and certain sectors, such as gambling, tobacco, and military production are prohibited. ${ }^{65}$

For direct financing or loan guarantees, a U.S. debt or equity investor must assume a "meaningful share of the risk, generally in the range of $25 \%$ of the project cost." ${ }^{\prime \prime 6}$ This U.S. connection can be a U.S. citizen, a juridical entity created

54. Id. at $\$ 2191(1)$.

55. Id. at $\$ 2191(2)$. The statute on its face does not specify a time frame, but this figure is presumably per capita income per year.

56. Id. at $\$ 2191(\mathrm{e})(1)$.

57. Id. at $\$ 2191(3), \S 2191(\mathrm{n})$.

58. Id. at $\$ 2191(\mathrm{j})$.

59. Id. at $\$ 2191(\mathrm{~g})$.

60. Id. at $\S 2191(\mathrm{k})$.

61. Id. at $\$ 2191(\mathrm{~m})$.

62. Id. at $\S 2191(\mathrm{~h})$.

63. Carl B. Kress, The United States Government and Post-Conflict Economic Reconstruction, 11 U.C. Davis J. Int'l L. \& Pol'y 75, 94 (2004).

64. Program Handbook, supra note 52, at 5-10.

65. OPIC, Investor Screener, www.opic.gov/doingbusiness/investor/index.asp (last visited March $28,2008)$.

66. Program Handbook, supra note 52, at 14. 
under the laws of the U.S., a foreign corporation more than 95 percent owned by U.S. investors, or any other foreign entity with 100 percent U.S. ownership. ${ }^{67}$ Loan amounts can be from $\$ 100,000$ to $\$ 250$ million per project, or $\$ 400$ million for certain oil and gas sector projects. ${ }^{68}$

In addition to providing direct financing or loan guarantees, OPIC provides political risk insurance to individual projects. Broad categories of coverage include Inconvertibility Coverage, which protects income and returns against blockage; Expropriation Coverage, which protects the net book value of the insured investment; and Political Violence Coverage, which protects physical assets and replaces lost income ${ }^{69}$ Insurance provided by OPIC is only available to U.S. citizens, U.S.-owned corporations, partnerships, or associations that are headquartered in the United States, foreign corporations more than 95 percent owned by U.S. investors, or other foreign entities with 100 percent U.S. ownership. ${ }^{70}$ In addition, investors must register their project with OPIC prior to the start of the project ${ }^{71}$ and are subject to the same developmental impact information requirements as for project finance. ${ }^{72}$

\section{B. Investments in the Caucasus and Central Asia}

Since 1990 OPIC has directly supported thirty-nine projects in the Caucasus and Central Asia. ${ }^{73}$ Its first commitments were made in fiscal year (FY) 1993, and currently projects in all eight countries are eligible for OPIC support. ${ }^{74}$ Total support in the thirty-nine projects committed to through FY2005 has amounted to $\$ 212,457,000$ in project financing and $\$ 865,934,175$ in project insurance. ${ }^{75}$ The

67. Investor Screener, supra note 65.

68. Program Handrook, supra note 52, at 16.

69. Toy, supra note 52 , at 188.

70. Program HandBook, supra note 52, at 24.

71. Id. at 41 .

72. OPIC, Ten Tipsfor the Investor Seeking OPIC Insurance, http://www.opic.gov/pubs/handbooks/ guides/tentips.asp (last visited March 28, 2008).

73. Support from OPIC requires a bi-lateral investment agreement between the United States and the country in which the project is contemplated. Such bilateral agreements were signed between the U.S. and all 8 Caucasus and Central Asian states between April and October 1992. See OPIC, Doing Business with Us-Europe and Eurasia, http://www.opic.gov/doingbusiness/our work/europe/ (last visited March 28, 2008) for copies of the various agreements.

74. See $i d$. for a list of countries in which OPIC can support projects, as well as links to bilateral investment treaties with those countries where they exist.

75. Email from Eli Landy, FOIA Director, OPIC, to Blake Puckett (Aug. 9, 2006) (on file with author); Excel spreadsheet "OPIC NIS commitments post 1990 for blake puckett FOIA," received Aug. 9, 2006 [hereinafter OPIC Spreadsheet] (on file with author). 
outcomes of these projects, while not uniformly grim, must give pause to future investors in the region. Of the thirty-nine projects, seventeen were either never implemented, have since failed, or have experienced serious corruption issues. ${ }^{76}$ Four were for non-profit corporations much less vulnerable to FCPA liability. Two projects appear to be doing well, but have been in place less than two years apiece. ${ }^{77}$ One was for the minimal OPIC investment of $\$ 100,000 .^{78}$ The remaining projects include five hotels, ${ }^{79}$ a travel agency, ${ }^{80}$ a telecommunications venture, ${ }^{81}$ the

76. See infra Part III.B.1-6. Projects by Conlan \& Associates in Georgia, MI Drilling Fluids LLC in Kazakhstan, and Torch Energy Advisors in Kazakhstan \& Turkmenistan were never implemented. I was not able to find any further information on the Conlan \& Associates project and the fact that OPIC funded a similar project in Georgia two years later suggests it never got beyond the planning stage. According to the SEEN website, http://www.seen.org/db/Dispatch? action-History:go $=1$ s index $=1$ (last visited March 28, 2008), the other three projects were not implemented. The others were Pacific Island Aviation, Inc. (see Harnish, supra note 48 and 2003 WLNR 1766495 for information on the failed Caucasus Airline), KAMED Financing (for an account of the corruption around this project see Michael Dodd, U.S. Plan To Control Bioweapons Falters: The Program Was Supposed to Find Peaceful Pursuits for Former Soviet Scientists, but Many of Them Feel Abandoned, Contra Costa Times, Sept. 17, 2000, at A32), and MCT/COSCOM of Uzbekistan.

77. OPIC, U.S. Small Business Uses OPIC Loan to Develop Leasing Industry in Georgia (Aug. 6, 2004), http://www.opic.gov/news/pressreleases/2004/pr080604.asp. See OPIC Spreadsheet, supra note 75, for more information on Baku Oil Tools, Ltd.

78. See OPIC Spreadsheet, supra note 75, for information on the use of these funds for trade show exhibition stands for TNT Productions Int'l, Inc.

79. These hotels are: the Marriott Hotel in Yerevan, Armenia, the Marriott Hotel in Tbilisi, Georgia, the Hyatt Hotel in Bishkek, Kyrgyzstan and two small hotels in Uzbekistan. See OPIC Spreadsheet, supra note 75 . While all of these projects are still ongoing, this does not mean they are free from corruption. The Marriott Hotel project in Yerevan was backed by Bob Walsh, a close friend of the corrupt former President Eduard Shevardnadze. See Paul Freeman, Walsh, Allies Creating Georgian Business Empire, Puget Sound Business Journal, Feb. 20, 1998, http://www. bizjournals.com/seattle/stories/1998/02/23/focus8.html. The Hyatt Hotel in Bishkek is partially owned by the municipality of Bishkek, prior to the Tulip Revolution in 2005 considered one of the most corrupt governmental agencies in Kyrgyzstan. Eur. Bank for Reconstruction \& Dev., EBRD to Join Forces with Hyatt International in Kyrgyzstan to Fund First Privately Financed, International Standard Hotel in Central Asia (Nov. 27, 1997), http://www.ebrd.com/new/pressrel/1997/87nov27x. htm; Interview with local Bishkek lawyer (2002).

80. The Levon Travel Bureau with offices in Yerevan. OPIC Spreadsheet, supra note 75.

81. MCT and its local affiliate COSCOM, who received $\$ 33$ million in OPIC insurance in FY1998. Id. MCT exited the market in 2007 with its acquisition by Fintur Holdings. Fintur Holdings B.V., TeliaSonera Closes the MCT Acquisition for SEK 2.0 Billion (July 17, 2007), www.fintur holdings.com/doc/MCT_Closing_Release_July\%2017.pdf. 
Kumtor Gold Mine, ${ }^{82}$ and the Baku-Tbilisi-Ceyhan Pipeline. ${ }^{83}$ Finally, three projects demonstrate the growing trend towards creating an arm's-length distance between OPIC and potentially corrupt emerging market partners that will be discussed more fully in Sections IV-V. ${ }^{84}$

A review of six of the least successful projects confirms the earlier assessment of the difficulties involved with investing in the region. The following examples highlight the degree to which the twin challenges of corruption and other governmental interference have affected investments in the region.

\section{Metromedia International Group}

According to the OPIC Freedom of Information Act (FOIA) release, Metromedia International Group, through two subsidiaries, received insurance coverage for telecommunications investments in Georgia and Uzbekistan. Insurance for $\$ 7,579,000$ was provided in FY1993 for an investment in Ayety TV, and insurance for $\$ 8,575,926$ was provided in FY1995 for an investment in the Georgian Communications Company and insurance for $\$ 5,112,283$ was provided in FY1993 for an investment in Kalamak TV in Uzbekistan. ${ }^{85}$ While Metromedia still owns Ayety and Kalamak TV, ${ }^{86}$ it is unclear whether the Georgian Communications Company project was ever completed. What is interesting to note is that Metromedia's cellular

82. OPIC provided $\$ 192$ million in political risk insurance to Chase Manhattan Bank to support its investment in the mine. The mine has since become a major factor in Kyrgyzstan's economy, accounting for some $6 \%$ of GDP. The Economist Intelligence Unit, Kyrgyzstan Country Profile 2006 at 24, 26.

83. The Baku-Tbilisi-Ceyhan (BTC) Pipeline has had relatively small participation by OPIC ( $\$ 141,800,000$ insurance coverage), with far greater sums by private investors and other international agencies. Mark Mansley, The Baku-Tbilisi-Ceyhan Pipeline and BP: A Financial Analysis at 19-24 (PLATFORM 2003). While the BTC Pipeline is operational, there are significant issues at play, including both corruption concerns, id. at 16-18, and environmental concerns, particularly in the wake of failures in BP's Alaskan pipelines. See Friends of Earth, Inc. v. Watson, No. 02-4106, 2005 WL 2035596 (N.D. Cal. Aug. 23, 2005) (denying summary judgment for defendant OPIC in suit alleging failure of OPIC to conduct proper environmental impact studies in oil \& gas projects); Stephen Foley, After Alaska, BP Faces New Pipeline Crisis, The Independent U.K., Aug. 12, 2006, at 28 . Note that the projects listed do not add up to 39 as some may actually include two projects, a financing project and an insurance project.

84. Two loan facilities, one through Wachovia Bank and one through National City Bank, each for $\$ 25$ million, to fund retail loan portfolios and one insurance contract to cover a leasing arrangement for two oil rigs in the Caspian Sea by Pride International, Inc. OPIC Spreadsheet, supra note 75.

85. Id.

86. Metromedia Int'l Group, Inc., Annual Report (Form 10-K), Exhibit 21 (Dec. 31, 2002), available at http://sec.edgar-online.com/2004/05/26/0000950129-04-003626/Section37.asp. 
project in Georgia, MagtiCom, has been implicated in corruption charges directed against ex-President Shevardnadze's son-in-law Gia Jokhtaberidze. ${ }^{87}$ In addition, Metromedia reported that certain employees involved in projects in the former Soviet Union might have violated the FCPA. ${ }^{88}$

\section{Belfinance}

According to the OPIC FOIA release, Belfinance received $\$ 4,817,000$ worth of insurance from OPIC for an investment in the Absolute Bank of Georgia in FY 1995. ${ }^{89}$ Absolute Bank was established in 1994 by a group of private U.S. investors, including L. Lloyd, President of Belfinance, who owned 60 percent of the share capital, together with a group of Georgian enterprises and individuals, who owned the remaining 40 percent. ${ }^{90}$ By 1997, the Bank was one of the largest in Georgia, and remained so until it was declared insolvent in May 2001. ${ }^{91}$ Insolvency was likely related to an investigation by the Georgian Interior Ministry in early 2001 into a $\$ 1.7$ million illegal withdrawal possibly connected to the Bank's Vice-President. ${ }^{92}$

\section{Chaparral Resources, Inc.}

According to OPIC, a commitment was made in FY1996 for insurance coverage of $\$ 50$ million to Chaparral Resources, Inc., for "oil field development" in Kazakhstan in conjunction with Karakuduk Munay, Inc. ${ }^{93}$ Although no insurance contract may have been issued ${ }^{94}$ Chaparral's project with Karakuduk did move forward. In May 2002 Chaparral was effectively purchased by a subsidiary of LukOil, which provided a fresh infusion of capital while settling accounts with Shell Capital-including the termination of legal proceedings by Shell. As a condition of this

87. Shevardnadze's Relative Sentenced to Pre-Trial Detention, UNA Georgia Online Magazine, Feb. 22, 2002, http://www.civil.ge/eng/print.php?id $=6272$.

88. Metromedia Discloses Possible Broken Laws, N.Y. Times, Nov. 27, 2002, at C4.

89. OPIC Spreadsheet, supra note 75.

90. U.S. Government Printing Office, More EBRD Lending in Georgia (Apr. 1997), http:// permanent.access.gpo.gov/lps1733/9704go.htm.

91. Georgian Economic Trends, 2001, No. 1, at 4, available at http://geplac.org/publicat/ economic/archives/get 01 nle.pdf.

92. An Absolute Scandal in U.S.—Georgia Absolute Bank, SArke Wkly. Press Dig., Feb. 25, 2001, available at 2001 WLNR 129692.

93. OPIC Spreadsheet, supra note 75.

94. See Sustainable Energy \& Econ. Network, Project Profile: Karakuduk Oil Field Development, http://www.seen.org/db/Dispatch?action-ProjectWidget:253-detail =1. 
restructuring, Chaparral "terminated its political risk insurance coverage with OPIC." ${ }^{\text {Ms }}$ Whether or not an actual insurance contract was operative at the time, what is most noteworthy is that LukOil made its termination a condition of its involvement. This demonstrates, at least in the minds of the U.S. competitors in the region, the oversight role that OPIC can play in direct project investments.

\section{MK Gold Company}

OPIC committed to providing $\$ 87$ million in financing to the MK Gold Company in FY1994 for a project at the Jerooy site in Kyrgyzstan. ${ }^{96}$ By 1996 MK Gold had ceased work on the project as disputes arose between it and Kyrgyzaltyn, the state-owned Kyrgyz national gold company and 70 percent owner of the Jerooy joint venture. Though Kyrgyzaltyn initiated arbitration proceedings against MK Gold, MK Gold won and was released of any liability and a liability to $\mathrm{MK}$ Gold of $\$ 2.5$ million was set, should the Jerooy site ever be put into production by another joint venture. ${ }^{97}$

Since the collapse of the joint venture with MK Gold, Kyrgyzaltyn has recruited a number of other partners for the development of the Jerooy site. The most recent, Oxus Resources of the United Kingdom, has been engaged in legal and regulatory battles with Kyrgyzaltyn for much of the past two years. ${ }^{98}$ That Oxus has seen its representative in Bishkek attacked and injured by gunmen, and

95. Chaparral, Annual Report (Form:10-Q) at 14 (Aug. 19, 2002) available at http://sec.edgaronline.com/2002/08/19/0001050502-02-000687/Section6.asp.

96. OPIC Spreadsheet, supra note 75. According to an MK Gold press release OPIC also committed up to $\$ 158$ million to provide political risk insurance to MK Gold and project lenders. This raises the question to what extent the OPIC provided spreadsheet accurately reflects all commitments made by OPIC within the region. See http://www.ratical.org/ratville/CAH/oilwarl.html (describing an OPIC commitment to Enron in Uzbekistan in 1996, which is not mentioned at all in the OPIC Spreadsheet). At a minimum, it suggests that in some cases the spreadsheet may not cover insurance provided to a company which also directly received project financing. $M K$ Gold Announces Government Approval of Kyrghyz Project; Completes Negotiations with Partner; Project Moves to Final Design and Construction, Business WIRE, Dec. 29, 1994, available at http://www .findarticles.com/p/articles/mi_m0EIN/is_1994_Dec_29/ai_15970047.

97. MK Resources, Annual Report (Form 10-Q), at 6 (Aug. 14, 1996), available at: http://sec.edgaronline.com/1996/08/14/00/0000898430-96-003793/Section7.asp; MK Resources, Annual Report (Form 10-Q), at 14 (Nov. 14, 1996), available at http://sec.edgar-online.com/1996/11/14/00/00008984 30-96-005307/Section9.asp. The arbitration ruling was confirmed in Oxus Resources Corporation Annual Report 2000, which indicated Oxus would underwrite the first $\$ 1$ million. Oxus Gold, ANNUAl Report \& AcCounts, at 48 (2000).

98. Jon A. Nones, Oxus Gold Hit by Shakedown in Uzbekistan, Resource Investor, Aug. 15, 2006, http://www.resourceinvestor.com/pebble.asp? relid $=22863$. 
its facilities adjacent to the site occupied, indicates once again the challenges to investing in the region..$^{99}$

\section{TK Tel Ltd (KATEL)}

TK Tel Ltd. received a commitment from OPIC in FY1995 for $\$ 24.5$ million in insurance coverage for the KATEL Joint Venture for the provision of a cellular telephone system. ${ }^{100}$ In 1997 the Kyrgyz government revoked KATEL's license for the operation of an international telecommunications (satellite) link. Concerns over this "confiscation" continued through 2002, and included intervention by the U.S. Ambassador to Kyrgyzstan and lobbying on behalf of KATEL prior to President Akaev's visit to Washington, D.C. in 2002. ${ }^{101} \mathrm{KATEL}$ has continued to operate in Kyrgyzstan, though it is far behind its competitor Bitel in market share. Bitel itself remains mired in corruption charges and a fight between Russian and Kazakh investors over its ownership. ${ }^{102}$

\section{Newmont Mining Corp.}

According to OPIC, the Zarafshon-Newmont Project in Uzbekistan has received three commitments for the provision of insurance, one to Newmont Mining Corp. in FY1994 for $\$ 15.75$ million, one to Chemical Bank in FY1994 for $\$ 6.074$ million, and one to Newmont Gold Co. in FY1995 for $\$ 103.5$ million. ${ }^{103}$ Operations at Zerafshon have been proceeding since they began in 1995. However, in the summer of 2006 Newmont came under intense pressure from the Uzbek government. Authorities have sought to declare the operation bankrupt and have begun a criminal probe of the local joint venture. According to Newmont, the government has also taken control of operations at the mine. Ostensibly, these actions are over Uzbek claims that the Zarafshon-Newmont joint venture owes $\$ 48$ million in back taxes. However, industry and regional observers have

99. Oxus Gold, Oxus Seeks Order from Arbitration Tribunal to Protect Investment (Sept. 11, 2006), http://www.oxusgold.co.uk/press-releases_200.asp.

100. OPIC Spreadsheet, supra note 75.

101. Bruce Fein, Early Test of Security Strategy, WAsh. Times (D.C.), Sept. 24, 2002, at A18, available at 2002 WLNR 395420.

102. Daniel Kimmage, Kyrgyzstan: Follow The Money - The Akaev Investigation, RadioFreeEurope/RadioLiberty, May 4, 2005, http://www.rferl.org/featuresarticle/2005/05/44deaece-777c4828-8lee-5a6e54d29562.html.

103. OPIC Spreadsheet, supra note 75. 
suggested that the measures are more likely tied to officials' desires to more fully benefit from the lucrative mine during this period of high gold prices. ${ }^{104}$

\section{Alternatives to Traditional OPIC Financing}

Projects supported by OPIC in the region have generally fared poorly, and a fair number have been brought down by corruption, either internally, or through government action clearly inimical to the rule of law. Three alternatives have emerged to OPIC's support of specific projects. ${ }^{105}$ In all three cases the alternative includes the imposition of a third party between the policy enforcing body and the project toward which funds are being directed. I argue that one reason these alternatives seem so attractive is that they mask the problem of corruption. They do this by decreasing the transparency of OPIC's funding and at the same time reducing OPIC's own internal capability to monitor funded projects for violations of various OPIC standards.

\section{A. Enterprise Funds}

The United States has developed two vehicles for financing investments in emerging economies as alternatives to traditional direct project financing by OPIC. One alternative, originally authorized by Congress in 1989 under the Support for East European Democracy (SEED) Act, ${ }^{106}$ are Enterprise Funds, defined by the U.S. Agency for International Development (USAID) as "independent organizations designed to encourage public-private sector investments and finance in countries transforming from a centrally planned to a free market economy. Funds were governed by a private-sector board of directors, but with U.S. government oversight of their operations." 107

Ten Enterprise Funds founded between 1990 and 1995 targeted the countries of Eastern Europe and the former Soviet Union. Of these, seven had a net loss when

104. Gulnoza Saidazimova, Uzbekistan: Government Takes On U.S. Gold Mining Company, RadioFreeEurope/RadioLiberty, Aug. 15, 2006, http://www.rferl.org/featuresarticle/2006/08/ 6fde678c-57f5-4490-aab9-2647f63d2d0a.html.

105. Arguably a fourth alternative is the move towards supporting small business projects, as these may not face the same corruption vulnerabilities that large-scale infrastructure projects do.

106. Press Release, USAID, Enterprise Funds, Nov. 5, 2001, available at http://www.usaid.gov/ press/releases/2001/pr011105_2.html.

107. USAID, USAID Primer: What We Do and How We Do It 39 (2006), available at http:// www.usaid.gov/about_usaid/PDACG100.pdf. 
liquidated, ${ }^{108}$ and two funds failed due to mismanagement, including the Central Asian Fund, which saw the eventual conviction of two of its vice-presidents for fraud and FCPA violations. ${ }^{109}$

\section{B. OPIC Investment Funds Program}

In contrast to Enterprise Funds, which were set up and funded by the U.S. government and for which the government maintained some responsibility, the second alternative is OPIC Investment Funds: "privately owned, privately managed investment vehicles that are partially supported by long term loans and U.S. government guarantees." 110 The government guarantees come from OPIC, and, to some extent, OPIC maintains a degree of oversight over projects funded by the private equity fund, including ongoing reviews of each fund and monitoring individual fund portfolio companies to ensure they meet OPIC standards with regard to U.S. economic and environmental impacts, host country development impact, and worker and human rights. ${ }^{111}$ In return for focusing on OPIC-dictated sectors and/or countries, these equity funds are able to mobilize capital for emerging markets by receiving guarantees (loans) from OPIC for a portion of their startup capital. OPIC becomes the senior debtor, and thus is first in line for funds when the investment funds are liquidated. Other partners (equity investors) only receive a return once OPIC has been repaid. ${ }^{112}$

OPIC, in supporting the use of investment funds, argues that private equity capital is "widely recognized as a key engine of entrepreneurial activity, technical innovation, job creation, and economic growth." ture capital is not widely available in emerging markets and so OPIC has stepped in to fill this gap. ${ }^{114}$

Critics of the program contend that OPIC Investment Funds, particularly during the 1990s, evinced a loss of focus on OPIC's developmental mission, were

108. Carol Lancaster, Foreign Aid and Private Sector Development 30 (Watson Inst. for Int'l Stud.), http://www.watsoninstitute.org/pub/ForeignAid.pdf. This holds true even when excluding the additional costs of operating expenses.

109. USAID, Press Release (Sep. 18, 2002), available at http://www.usaid.gov/oig/press/091802.pdf.

110. LANCASTER, supra note 108 , at 4.

111. USAID, Investment Funds 2 (2004), available at http://www.opic.gov/pubs/investment funds9-04.pdf.

112. Program Handbook, supra note 52, at 44.

113. Id. at 43 .

114. Id. 
a form of corporate welfare for the fund managers, failed to provide an adequate return, and lacked transparency. ${ }^{115}$

Private equity funds in general are largely opaque to outsiders; there are no reporting requirements other than to their partners. OPIC-backed investment funds suffer from this opacity, with only limited exceptions. They are required to submit reports to OPIC on their various portfolio projects, but these reports are considered confidential business information and so are not subsequently available to the general public under the FOIA. ${ }^{116}$ In addition, OPIC-backed Investment Funds are not subject to the accounting requirements of the FCPA. ${ }^{117}$ Finally, despite criticism over their lack of transparency, OPIC has not released information on the funds' performance. ${ }^{118}$

\section{OPIC-Backed Banking}

A third vehicle, the provision of financing to banks in order to establish loan or micro-credit programs, is still categorized by OPIC as project funding, but the distancing relationship between OPIC and the emerging market is similar to that of the funds. In Central Asia, OPIC has provided two loan facilities, one through Wachovia Bank and one through National City Bank, each for $\$ 25$ million, to fund retail loan portfolios. Like the Enterprise and Investment Funds, the use of international banks as a project partner does result in the injection of more credit into the local economy. And unlike the other two approaches, the banks remain subject to the full panoply of social and environmental requirements prior to the approval of the project. However, once the project is approved the oversight becomes much less direct. In the case of Wachovia and National City, these funds were then transferred to TuranAlem Bank of Kazakhstan to provide additional funds to "expand the retail and consumer lending activities" and to "fund [a] retail loan portfolio" respectively. ${ }^{119}$ Both U.S. banks, and by extension OPIC, be-

115. See Lancaster, supra note 108, at 59; see also Janice Shields, Investment Funds, Foreign Pol'y in Focus, Vol. 2, No. 44, Aug. 1997, available at http://www.fpif.org/briefs/vol2/v2n44inv.html.

116. OPIC, Form 217- Self Monitoring Questionnaire, at 1, available at http://www.opic.gov/ forms/Form217-smq_063007_funds.doc.

117. This is because, as private limited partnerships, they are not required to file reports with the SEC. But see Kevin M. LaCroix, SOX and the Private Company, INSights, Issue 2, at 1 (OakBridge 2006), available at http://www.oakbridgeins.com/SOX\%20Private\%20Company\%20issue\%20 2\%204-06.pdf (arguing that Sarbanes-Oxley has led to growing view that corporate governance "best practices" apply to private companies).

118. LanCaster, supra note 108 , at 66.

119. OPIC Spreadsheet, supra note 75. 
came well insulated from any local corruption, and yet at the same time will have little if any influence over TuranAlem's lending strategy and potentially corrupt local dealings. The relationship is at arm's length, and hence the impact of the FCPA will be minimal at best. Even in the unusual case where a U.S.-based bank were to set up its own lending office, the capital would still be used by an organization not subject to OPIC's oversight.

\section{Analysis of Trends}

While it is unclear to what extent the recent approval of two bank projects in Central Asia is the start of a regional trend, if one steps back and looks at the larger picture, a clear trend appears in OPIC's use of arm's-length funding mechanisms. In FY1997, OPIC's Board of Directors approved resolutions authorizing financing of $\$ 552$ million as part of the capitalization of five investment funds while approving resolutions for direct financing of $\$ 538$ million for five projects. In FY1998 the Board of Directors approved resolutions authorizing financing of $\$ 60$ million as part of the capitalization of one investment fund while approving resolutions for direct financing worth a total of $\$ 427$ million for four projects. In addition, the Board approved financing for an on-lending facility for Citibank, N.A. of up to $\$ 100$ million. In contrast, for FY2005 and FY2006 the numbers are much more skewed towards investment funds and bank lending facilities. Specifically, in FY2005, $\$ 375$ million went to seven investment funds and $\$ 1.007$ billion went to seven bank lending facilities in contrast to $\$ 289.6$ million in direct financing for three projects. In FY2006, $\$ 350$ million went to seven investment funds and $\$ 895$ million went to five bank lending facilities in contrast to $\$ 100$ million in direct financing for one leasing project. ${ }^{120,121}$

\section{E. Arguments for the Trend}

Various arguments can be made for this increase. It may increase FDI in places where U.S. companies are not willing or able to make the investment themselves.

120. This data was compiled from a list of OPIC Board Resolutions available at www.opic.gov/ pubs/foia/resolutions/index.asp (compilation on file with author). Board resolutions are only required for projects above a certain value, so to some extent the data presented here overemphasizes the financing of bank lending and investment funds. Nevertheless, the trend remains the same.

121. While a leasing project is considered a direct financing project, the actual user of the capital is the lessor, and once again OPIC is maintaining an arm's length relationship. 
More generally, Knill has argued that foreign portfolio investment ${ }^{122}$ increases the availability of credit to small firms, and, at least in countries with developed property rights, also leads to growth. ${ }^{123}$ Others have argued that the involvement of private equity firms leads to better corporate governance and greater transparency, as these are the expectations of investors to whom the equity firms are hoping to sell at a profit. ${ }^{124}$ Regardless of the economic argument in favor of the increased use of funds, concerns about transparency and corruption must be addressed.

\section{Anti-Corruption and Transparency}

\section{A. Less Oversight}

Until recently, OPIC had not been greatly concerned about corruption and the FCPA. In its Investment Policy, OPIC lists the following congressionally mandated concerns regarding OPIC-approved projects: that they "apply consistent and sound environmental standards, apply consistent and sound worker rights standards, observe and respect human rights, have no negative impact on the U.S. economy, and encourage positive host country development effects." ${ }^{25}$ While OPIC requires an Environmental Impact Statement for projects likely to have a detrimental impact on the environment, there is no requirement by OPIC for an investor to lay out how it will avoid corrupt payments in regions of the world where corruption is a known and common problem, such as the Caucasus and Central Asia. Instead, OPIC merely requires project sponsors to covenant that they will abide by FCPA and other relevant anti-corruption laws and regulations. ${ }^{126}$ OPIC's 2005 Annual Report does not even mention the word corruption, and a search of OPIC's website for "corruption" in September 2006 revealed only six hits, only one of which dealt with reducing corruption as part of OPIC's developmental goals. ${ }^{127}$ Indeed, one of the other hits concerned the award on an expropriation insurance claim despite the assertion

122. For the difference between Foreign Portfolio Investment and Foreign Direct Investment, see generally Klein, supra note 2 .

123. See Knill, supra note 3, at 3-4.

124. Cf. Program Handbook, supra note 52, at 44.

125 OPIC, Investment Policy, http://www.opic.gov/doingbusiness/investment/ (last visited March 28,2008 ).

126. Given the far greater criminal and monetary penalties involved in a violation of the FCPA, a signed covenant with OPIC seems redundant.

127. OPIC, Annual Report (2005), available at http:/www.opic.gov/pdf/05_AnnualReport. pdf (no hits for "corruption"); OPIC, Development Update (2003), available at http://www.opic .gov/pdf/02_DevelopmentReport.pdf (one hit for "corruption"); OPIC, ANti-Corruption Poli- 
by the sovereign nation that corruption had been involved in the initial awarding of the project. OPIC cited the lack of any substantiation of the corruption assertion in justifying its awarding of the insurance claim. ${ }^{128}$

Recently OPIC has responded to these concerns with a new initiative to combat corruption and improve transparency. ${ }^{129}$ Reforms include the publication of an Anti-Corruption Handbook, the establishment of a corruption hotline, the adoption of a Statement of Principles endorsing the Extractive Industries Transparency Initiative, and an increase in information posted on the web, including Board of Directors resolutions and brief summaries of new OPIC sponsored projects. ${ }^{130}$

But the effectiveness of these initiatives is unclear. Despite these improvements, determining the extent of OPIC involvement in projects remains a daunting task. There remains no comprehensive list of active projects to which OPIC has a financial or insurance commitment on the website, let alone a list of projects funded by Investment Funds or loan facilities. Even after obtaining a list of projects in Central Asia and the Caucasus under the Freedom of Information Act, I was denied the additional information necessary to determine with whom and in what way the U.S. investor was partnered with local parties. ${ }^{131}$

If the ability to conduct external monitoring is still lacking, internal monitoring also faces severe challenges. According to OPIC's FY2007 Budget Request, the Corporation saw "an annual increase in the number of projects of $+23.8 \%$ and $+9.2 \%$ in 2004 and 2005 respectively-all within an essentially static budget." ${ }^{.132}$ The fact that these numbers do not include subprojects and fund investments suggests the growing challenge for OPIC of monitoring its projects, particularly as new emphasis is placed on measuring developmental and additionality goals. ${ }^{133}$ Finally, the Budget Request revealed that while OPIC's publicity is trumpeting its new efforts to measure the contribution of OPIC-sponsored projects to develop-

CIES AND STRATEGIES HANDBOoK (2006), available at http://www.opic.gov/pubs/handbooks/guides/ documents/opicanticorruptionhandbook0906.pdf (19 hits for "corruption").

128. OPIC, Memorandum of Decisions 5 (2006), http://www.opic.gov/insurance/claims/ report/documents/claim_mid_american.pdf.

129. OPIC, OPIC Implements New Initiative to Combat Corruption and Improve Transparency (Sept. 21, 2006), available at http://www.opic.gov/news/pressreleases/2006/pr092106.asp.

130. Id.

131. Letter from Eli Landy, FOIA Director, OPIC, to Blake Puckett, Re: FOIA Case No. 2006-00043 (Oct. 24, 2006) (on file with author).

132. OPIC, Budget Request Fiscal Year 20074 (2006), available at www.opic.gov/about/ reports/documents/FY07BudgetRequest.pdf.

133. Id. at 6 . 
ment through a Development Matrix, no such matrix exists to evaluate either framework agreements (i.e., bank lending) or investment funds. ${ }^{134}$

The potential for Investment Funds to be involved in corruption when adequate oversight is not present has already been demonstrated. The Great Circle Fund, which is managed by the Alfa Group, an OPIC sponsored Investment Fund, was recently charged in court on federal racketeering allegations. ${ }^{135} \mathrm{Like-}$ wise, American International Group, which ran the AIG Brunswick Millennium Fund (an OPIC Investment Fund) ${ }^{136}$ recently saw one of its private equity group managing directors indicted on FCPA charges. ${ }^{137}$

In an article discussing means of ensuring international environmental justice, John Suttles argues that OPIC can be an effective "tool in the environmental justice arsenal" because it encourages public consultation, including input from both local and international nongovernmental organizations. ${ }^{138}$ OPIC is arguing that it is moving toward a more comprehensive developmental model with more extensive evaluation. However, its primary means of evaluation is currently based on self-reporting. To the extent that OPIC simultaneously continues to move toward the use of Investment Funds and bank-based loan facilities, there will be little or no means for independent input into these evaluations. FOIA does not reach into private banks or equity funds, and it becomes virtually impossible for independent observers to determine who is actually receiving OPIC-backed funds. Without this basic knowledge, there is no way for civil society to correct self-serving self-reporting. ${ }^{139}$ OPIC has proudly pointed to the creation of an Office of Accountability that can receive input from local communities and assess

134. Id. at 7.

135. Russian Oligarch Fridman, Corporation Sued for Racketeering, Fraud That Used U.S. Banks and Exchanges, PR Newswire, June 10, 2006, available at http://www.mirror99.com/20060610/ russian_oligarch_fridman_corporation_sued_for_racketeering_fraud_that_used_u_s_banks _and_djib.jspx. It is probably not helpful that Alfa hired former head of OPIC Peter Watson. See Alfa Group Hires Well-Known Politicians and Businessmen, Russian Finance Report, Sept. 22, 2006, available at 2006 W NR 16431711.

136. OPIC, Investment Funds, Full List of Funds, available at www.opic.gov/investment/ participating/fulllist/index.asp (last visited March 28, 2008).

137. U.S. Department of Justice, U.S. Announces Charges in Massive Scheme to Bribe Senior Government Officials in the Republic of Azerbaijan (Oct. 6, 2005), available at http://www.usdoj.gov/ usao/nys/pressreleases/October $05 /$ kozenyetalindictmentpr.pdf.

138. See John T. Suttles, Transmigration of Hazardous Industry: The Global Race to the Bottom, Environmental Justice, and the Asbestos Industry, 16 Tul. EnvtL. L.J, 1, 61-63 (2002).

139. Alfred A. Aman, Jr., The Democracy Deficit: Taming Globalization through Law REFoRM 3 (2004)("Democracy deficits may arise from decisions that have significant adverse affects on individuals but are inaccessible to affected citizens"). 
and review complaints about OPIC-supported projects. ${ }^{140}$ But without the knowledge of whom OPIC is supporting, communities have no opportunity to report.

\section{B. From Filling a Gap to Free Market and Back}

Initially, OPIC was chartered by Congress because U.S. companies were unable to access the funding or the insurance necessary to invest in the developing world. ${ }^{141}$ However, OPIC-like many policy-makers, economists, and development experts - has adopted an increased emphasis on the use of the private sector and the free market to move its development agenda forward. ${ }^{142}$ While the mobilization of private capital has always been part of OPIC's mission, individual projects were supervised by OPIC with developmental goals in mind. Now however, OPIC has turned control of project decisions over to private fund managers whose first priority must be to maximize profit. ${ }^{143}$

We are moving in the wrong direction; and the current approach to the FCPA is helping push us further along. While the growth in investment funds and other arm's-length financing options allows us to pump more money into a region's economies - this practice has a number of down sides.

First, it avoids the original goal of FCPA, which was to reduce corruption and its attendant social and political costs. Long-arm financing keeps OPIC and U.S. companies free from the taint of corruption, but it does little to ensure that local loan recipients push against local norms. Realistically, the push for funding of local concerns rather than the more traditional U.S. subsidiary or joint venture may in fact be a push to take advantage of such companies' abilities to operate in the local milieu-corruption, nepotism, connections, and all. ${ }^{144}$

Second, the current approach decreases the impact that western firms can

140. U.S. Department of Justice, supra note 137.

141. Jennifer M. DeLeonardo, Note, Are Public and Private Political Risk Insurance Two of a Kind? Suggestions for a New Direction for Government Coverage, 45 VA. J. INT'L L. 737, 740-42 (2005).

142. George Munzo \& James C. Brenner, Private Equity Funds 2 (unpublished manuscript), available at www.undp.org/ods/areas/area-3/area-mm/Brenner3edit.doc. See generally Aman, supra note 139, at 32 ("The principal hallmark of regulation in the global era has thus been the shift from state-centered, command-control regulation to deregulation, privatization, and market forms of regulation.").

143. See OPIC, Annual Report 5 (2005), available at http://www.opic.gov/pdf/05_Annual Report.pdf (President of OPIC extols "unleash[ing] the transformative power of the free market in even more emerging markets").

144. See generally Complaint, Omega Advisors, Inc. v. Lewis, No. 06-834, 2006 WL 807034 (S.D.N.Y. filed Feb. 2, 2006) (describing one fund's encounters with corruption in Azerbaijan). 
have on the ground. While equity funds promise the advantages of their financial and managerial expertise to local concerns, infrequent visits from fund managers and external experts are quite different from the prolonged presence of experienced management from the parent company in a typical FDI project. ${ }^{145}$ Indeed, even as the parent company seeks to raise up local talent (for cost reasons, if nothing else), the promise of a long-term relationship of mutual advantage between local management and the parent company remains. By contrast, the relationship of equity fund or lender to the local company lasts only for the life of the loan. Even in cases where the fund has made an equity investment, it is understood that the investment will be sold in the near future, preferably for a profit.

Finally, as an instrument of foreign policy, funds are just less impressive than direct foreign investment. ${ }^{146}$ While money may still be flowing into the local economy, the visible signs that these flows are from the U.S.- - to both the political elite and the average local citizen-will be far fewer. While equity funds may be providing investment capital — new machinery, new expertise, new product lines-- they are also expecting a relatively quick turn-around and profitable withdrawal. Difficult downsizing decisions will be made without the offsetting promise of a long-term presence. In stressing the benefits of favoring a western-oriented policy our diplomats need the full array of tools-including the ability to clearly point to U.S. FDIs, backed by the U.S. government, in the host nation. OPIC, of all the U.S. agencies associated with development, is the agency best equipped to mobilize for-profit U.S. firms to actually establish a local presence and contribute to the local economy. This is the new gap in U.S. development policy, and one that OPIC can fill. ${ }^{147}$

\section{Transparency \& Investment}

At the same time, the United States needs better mechanisms to support its FDIs. The increased emphasis on corruption at OPIC must be matched with new structures that allow companies to avoid FCPA sanctions. If the goal of greater transparency is achieved but no other changes in policy are made, some regions

145. A draft article by the former head of OPIC, George Munzo, confirms that private equity fund investments are "typically smaller, and somewhat more likely to be managed, at least in part, by local personnel." Munzo \& Brenner, supra note 142, at 2 .

146. Of course, when things go badly, the clear connection to the U.S. can have a much greater negative effect.

147. Kress, supra note 63, at 85-97 (noting functions of State Department, USAID, Treasury, USTDA, Commerce, and Ex-Im Bank, none of which is both developmental and concerned about setting up profitable companies). 
may not be open for U.S. investment. While one hopes for improvements stemming from a global emphasis on anti-corruption measures, there are competing investors, particularly in Central Asia and the Caucasus, who are willing to invest without the conditions attached. ${ }^{148}$

One possibility is to allow companies to report corrupt payments confidentially. ${ }^{149}$ This would be particularly appropriate for ongoing concerns where the investment costs have already been incurred and companies have little option other than to pay the bribe or lose their investment. Potentially, these reports could be filed for future use by the company and/or the local government in the event the governing climate changes.

Another possibility is tying investments to other projects designed to benefit the local community. Arguably investments in local infrastructure and social organizations by the investor and by other U.S. government organizations and partners could reduce the demand for corrupt payments-as officials receive benefits from the overall improvement in the community. The threat of removing the entire package could also work as a powerful deterrent should individual actors seek unfair gains. This suggests that OPIC would require additional funding beyond its current self-financing role, where, in addition to financing and insurance of the project itself, additional funding would be provided for these project add-ons in a grant-based effort.

Finally, the Development Matrix that OPIC has developed could be connected to legal or civil consequences. An initial survey, either of the project site or of a larger region could be done to set a baseline. Then the project, of which the OPIC-backed company would be the lead element, would be evaluated on the extent to which the community saw improvements across the board. Success could be linked to bonuses while lackluster performance could involve civil penalties, and if egregious enough, perhaps criminal penalties as well.

\section{Conclusion}

Emerging markets are a difficult place in which to invest. As OPIC's experience in Central Asia and the Caucasus shows, corruption and unreformed local

148. Jane Perlez, China Competes with West in Aid to Its Neighbors, N.Y. Times, Sept. 18, 2006, at A1, available at 2006 WLNR 16157771.

149. Another alternative would be to put it completely above board. If required by the law of the nation to pay service fees, or perhaps even to put local leaders in paid positions on a local board of directors or advisors, one can argue that the FCPA would exempt such payments from liability. See FCPA OPR, supra note 26. 
governments make FDI a difficult challenge. With limited interest in or potential for direct investment, and the belief that emerging markets need access to more capital, the United States has increasingly relied on intermediaries such as Enterprise Funds, OPIC-backed Investment Funds, or bank loan facilities, as tools of investment in emerging markets. But while these all serve to increase capital in developing economies, the distance they create between OPIC and the end-user fosters a lack of transparency and ultimately corruption. Greater transparency is needed, but in the face of systemic corruption, the United States cannot simply abandon the playing field to others less concerned about principles. U.S. strategic interests, as well as the continued desire to assist in the development of other countries, require a rethinking of our methods. Such considerations call for a balanced approach that tackles corruption, environmental concerns, worker rights, and the fundamental need for gainful employment. With the right support, OPIC has the potential to create such a system. 